\title{
ANTAGONISTIC EFFECT OF EDIBLE MUSHROOM EXTRACT ON CANDIDA ALBICANS GROWTH
}

\author{
Edneia A. de Souza Paccola ${ }^{1}$; Cristina Sayuri Maki²; Gisele M.A. de Nobrega²; Luzia Doretto Paccola-Meirelles ${ }^{2 *}$ \\ ${ }^{1}$ Departamento de Agronomia and ${ }^{2}$ Departamento de Biologia Geral, Universidade Estadual de Londrina, \\ Londrina, Paraná, Brasil
}

Submitted: February 02, 2001; Returned to authors for corrections: April 27, 2001; Approved: September 03, 2001

\section{SHORT COMMUNICATION}

\begin{abstract}
Five species of edible mushrooms, Lentinula edodes, Pleurotus ostreatus, Pholiota nameko, Macrolepiota bonaerensis and Agaricus blazei, were tested for their potential to inhibit the in vitro growth of the pathogenic yeast Candida albicans. Only L. edodes had a fungistatic effect on this human pathogen. The inhibitory compound was produced intra and extracellularly in submersed $L$. edodes culture, and was also present in fresh and dehydrated mushroom basidiocarps. The fungistatic compound was heat sensitive and lost activity after 72 hours.
\end{abstract}

Key words: mushrooms; antibiotics; candidiasis, fungistatic effect

Candida albicans is a yeast present in the human gastrointestinal and genital-urinary tracts, and is very frequent among the infections caused by fungi in immunedepressed individuals, diabetics, and HIV carriers. In cases of endocrinopathies such as hypothireoidism, hypoadrenalism, and diabets, there is an increase in the predisposition to candidiasis attributed to the increase in glycemia and immune deficiency, which often hinders treatment (6). The incidence of candidas also increases during pregnancy due to an increase in the concentration of glycogen by cells in the vaginal mucous tissues, causing disconfort to the patient (7). Extensive clinical studies, primarily in Japan, have clearly demonstrated that a number of mushroom species have medicinal and therapeutic value, in the prevention and treatment of tumors, viral and bacterial diseases, hypercholesterolemia and blood platelet aggregation $(1,2,4)$.

In this preliminary report we tested the antagonic potential of edible mushroom species Lentinula edodes, Pleurotus ostreatus, Pholiota nameko, Macrolepiota bonaerensis, and
Agaricus blazei Murill on C. albicans. Mycelia from each species was obtained by tissue culture from basidiocarps and kept in PDA medium (Potato Dextrose Agar). Discs of mycelia were transferred to potato broth and after 30 days growth at $25^{\circ} \mathrm{C}$ the mycelial growth substrate was obtained. An aliquot of $0.5 \mathrm{ml}$ of this substrate was added to tubes containing $5 \mathrm{ml}$ of potato broth added to a suspension of $10^{8}$ cells $\mathrm{ml}^{-1}$ of C. albicans (strain 577) (the cells were obtained by culture in potato broth for 24 hours at $25^{\circ} \mathrm{C}$ and washed three times in PBS by centrifuge). At 0, 24, 48 and 72 hours at $25^{\circ} \mathrm{C}$ the number of $C$. albicans cells was estimated in a Newbauer chamber and compared with the control (yeast grown in the medium without the mycelial growth substrate). Under these conditions, only the L. edodes mycelium, popularly known as shiitake, showed inhibitory action on $C$. albicans multiplication. The minimum dose of the mycelial growth substrate capable of inhibiting the multiplication of the C. albicans cells after 24,48 and 72 hours of exposure was $4 \%, 6 \%$ and $10 \%$, respectively (Table 1 ). The inhibitory agent is probably volatile or can be degraded or metabolized

\footnotetext{
* Corresponding author. Mailing address: Universidade Estadual de Londrina, Centro de Ciências Biológicas (CCB), Departamento de Biologia Geral, Caixa Postal 6001, 86051-990, Londrina, PR, Brasil. E-mail: paccola@uel.br
} 
Table 1. Inhibition of C. albicans multiplication in potato broth medium in presence of different concentrations of $L$. edodes mycelial extract ( $\mathrm{pH}$ 6.8).

\begin{tabular}{ccccc}
\hline L. edodes & \multicolumn{4}{c}{ Time of C. albicans growth (hours)* } \\
\cline { 2 - 5 } extract & 0 & 24 & 48 & 72 \\
\hline Control & $<10^{4}$ & $0.13 \times 10^{7} \mathrm{~b}$ & $0.17 \times 10^{7} \mathrm{~b}$ & $0.36 \times 10^{7} \mathrm{c}$ \\
$1 \%$ & $<10^{4}$ & $0.24 \times 10^{7} \mathrm{a}$ & $0.35 \times 10^{7} \mathrm{a}$ & $0.70 \times 10^{7} \mathrm{~b}$ \\
$2 \%$ & $<10^{4}$ & $0.14 \times 10^{7} \mathrm{~b}$ & $0.24 \times 10^{7} \mathrm{~b}$ & $1.10 \times 10^{7} \mathrm{a}$ \\
$4 \%$ & $<10^{4}$ & $0.03 \times 10^{7} \mathrm{c}$ & $0.23 \times 10^{7} \mathrm{~b}$ & $0.74 \times 10^{7} \mathrm{~b}$ \\
$6 \%$ & $<10^{4}$ & $0.01 \times 10^{7} \mathrm{c}$ & $0.20 \times 10^{7} \mathrm{~b}$ & $0.49 \times 10^{7} \mathrm{c}$ \\
$10 \%$ & $<10^{4}$ & $<10^{4} \mathrm{e}$ & $0.01 \times 10^{7} \mathrm{c}$ & $0.16 \times 10^{7} \mathrm{~d}$ \\
\hline
\end{tabular}

* means followed by same letters in the vertical don't differ significantly for Tukey's test $(\mathrm{p} \leq 0.05)$.

during the yeast growth period. When daily doses of $L$. edodes growth substrate ( $0.5 \mathrm{ml}$ every 24 hours) were added to the $C$. albicans culture, the number of cells remained constant and lower than $10^{4}$ units $\mathrm{ml}^{-1}$ of suspension, even after 72 hours incubation, showing the fungistatic effect of $L$. edodes on C. albicans. This fact prompted us to examine whether this antibiotic effect is kept in the mushroom in the form as it is consumed by man, fresh or dehydrated. Emerged basidiocarps from eucalyptus (Eucaliptus saligna) logs were used fresh and dehydrated. For dehydration, fresh mushrooms were placed in a dehydration chamber to $60^{\circ} \mathrm{C}$ until complete water loss. The dehydrated mushroom was ground to a fine powder and placed in infusion at the proportion of $6 \mathrm{~g}: 10 \mathrm{ml}$ distilled water. The fresh mushrooms were macerated in distilled water $(60 \mathrm{~g} / 150 \mathrm{ml})$. Part of this maceration was heated to $100^{\circ} \mathrm{C}$ for 10 minutes and the other part used fresh. The preparations were filtered in Watmann filter paper and in Millipore $0.45 \mathrm{~mm}$ and $0.22 \mu \mathrm{m}$ and applied to the C. albicans culture at different doses $(0,10,15,20$ and $30 \%)$. The number of yeast cells was estimated in a Newbauer chamber after 0,8 , 12,24 and $48 \mathrm{~h}$. After 24 hours, it was possible to observe the fresh L. edodes basidiocarp inhibitory effect, but after 48 hours of exposure to the inhibitory agent the cells returned to growth, confirming the fungistatic effect shown in Fig. 1. The same was observed when the powder of dehydrated mushroom was tested (Fig. 2).

Heat-treatment of the filtrate inactivated the inhibitory agent. Ishikawa (3) studied the inhibitory activity of L. edodes on Bacillus, Listeria, Staphylococcus, Acinetobacter, Citrobacter, Enterobacter, Escherichia, Klebsiella, Proteus, Pseudomonas, Salmonella, Serratia, Shigella and Yersinia, observing that the greatest activity was on Gram positive bacteria, as also observed by Komemushi et al. (5). However, this antimicrobial compound was shown to be heat stable, unlike the compound described in this study.

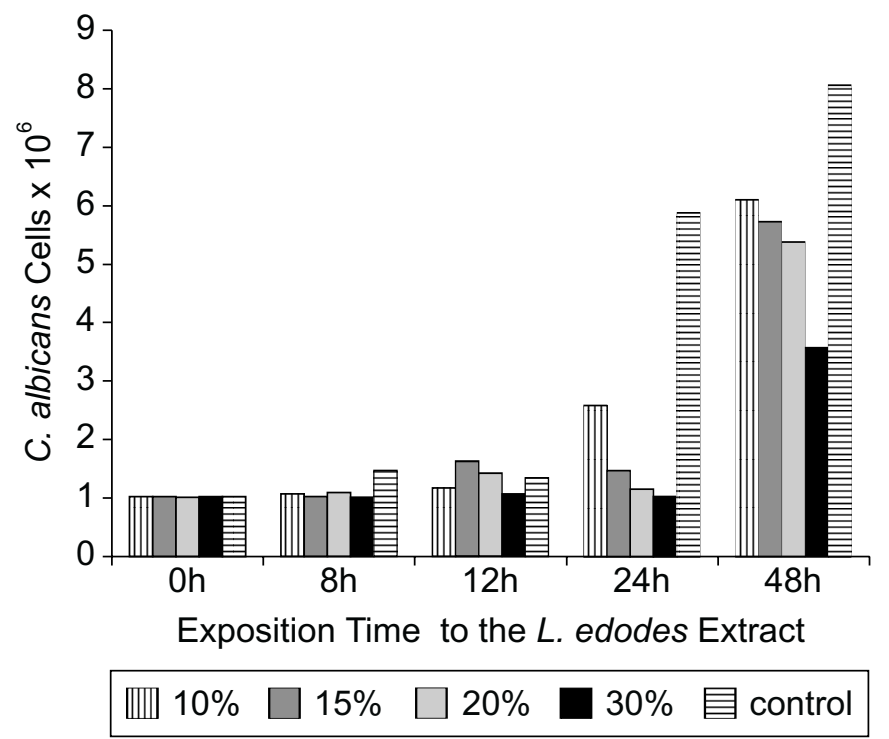

Figure 1. Effect of different doses of Lenticula edodes mycelial substrate on growth of Candida albicans.

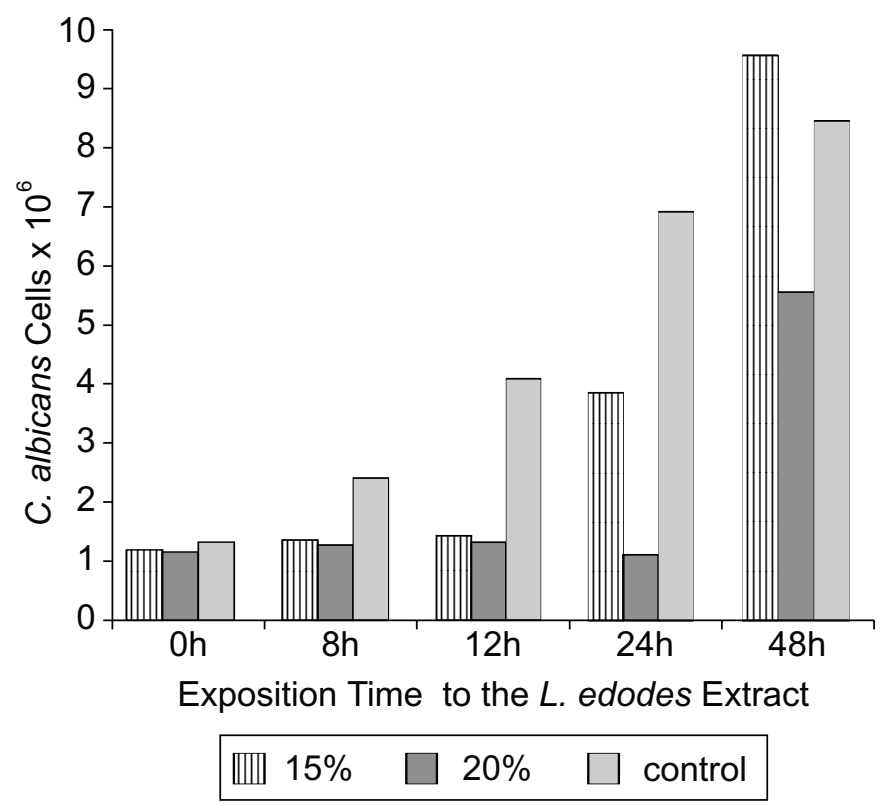

Figure 2. Effect of different doses of the dehidrated extract of L. edodes basidiocarps on growth of Candida albicans.

In conclusion, the findings of this study have shown that $L$. edodes produces a fungistatic agent, which is able to control $C$. albicans multiplication. The agent is present both in the basidiocarps and in the mycelia, which is secreted in the growth medium. This substance is heat sensitive and looses activity after 72 hours. 


\section{RESUMO}

\section{Efeito antagonístico de extratos de cogumelos comestíveis sobre Candida albicans}

Cinco espécies de cogumelos comestíveis, Lentinula edodes, Pleurotus ostreatus, Pholiota nameko, Macrolepiota bonaerensis e Agaricus blazei foram avaliadas quanto ao seu potencial em inibir o crescimento "in vitro" da levedura patogênica Candida albicans. Apenas a espécie L. edodes apresentou efeito fungistático sobre este patógeno humano. $O$ composto inibitório foi produzido intra e extracelularmente em cultivo submerso de L. edodes e também estava presente em basidiocarpos frescos e desidratados do cogumelo. O composto fungistático é termossensível e perde sua atividade após 72 horas.

Palavras-chave: cogumelos, antibióticos, candidíase, efeito fungistático

\section{REFERENCES}

1. Breene, W.M. Nutritional and medicinal value of specialty mushrooms. J. Food Protec., 53:883-894, 1990

2. Chang, S.T.; Buswell, J.A.; Miles, P.G. Genetics and Breeding of edible mushrooms. Gordon and Breach Science Publishers S.A. Amsterdam, 1991, 322p.

3. Ishikawa, N.K. Avaliação da atividade antagonista de Lentinula edodes. Viçosa, 1997. Dissertação-Mestrado em Microbiologia Agrícola. Universidade Federal de Viçosa - MG.

4. Jong, S.C.; Birmingham, J.M. Medicinal and therapeutic value of the shiitake mushroom. Adv. Appl. Microbiol., 39:153-184, 1993

5. Komemushi, S.; Yamamoto, Y.; Fujita, T. Purification and identification of antimicrobial substances produced by Lentinus edodes. J. Antifungal Ag., 24:21-25, 1996

6. Martins, J.E.C. Etiopatogenia e aspectos clínicos das candidíases superficiais, cutâneas e cutâneo-mucosas. In: Lacaz, C.S. (ed). Candidiases. São Paulo: Universidade de São Paulo, 1980, p.7988 .

7. Salvatore, C.A. Candidíase vulvovaginal. In: Lacaz, C.S. (ed). Candidiases. São Paulo: Universidade de São Paulo, 1980. p.113120 . 